\title{
EDUCATION IN THE “BENDING” OF THE MODERN POLITICAL LANDSCAPE
}

\begin{abstract}
The article formulates and justifies the idea that the problem of education is a timeless and universal social problem, on the solution of which depends on such things as the spiritual and moral health of a nation, the degree of its intellectual development, the limits of disclosing its creative potential, and through all this the stability of the state. The transition to an information society (the knowledge society) is reduced to the abandonment of the centuries-old tradition of the "culture of knowledge", which destroys the existential foundations of the person who produces and consumes this knowledge. To overcome these destructive trends for modern societies, it is expedient to revive the goals of the educational system determined by the national culture, the most important of which is the education of man as a spiritual and political being.
\end{abstract}

Keywords: information society, models of modern education, principles of state education, the human dimension of education, spiritual values of the nation, anthropological crisis, intellectual consumerism.

Introduction

The problem of education is considered as one of the most important issues of our time, which allows us to study it outside the framework of specific scientific disciplines (political, social and economic sciences) - in a cultural and civilizational vein.

The article highlights essential issues in the field of modern philosophy and methodology of science, such as education-politics, educationeconomics, education-social relations, education-science (knowledge), scientific education, educational policy.

The research peruses the following objectives:

1. Identifying and analyzing paradoxes of the modern education system, as a manifestation of the paradoxes of the modern culture.

2. Analysis and evaluation of the idea of knowledge as a condition of economic growth.

3. Determination of ways and means to overcome the paradoxes of modern education and culture systems.

... there is a powerful intellectual tradition of thinking about education and politics in their unity ... This tradition is diverse, but the common feature of many important texts that are being created so far is that education is viewed as part of large-scale political, often utopian, projects that construct "the best" ... of society. Today, the situation is similar (education remains largely an integral part of the neo-liberal political agen- 
$d a)$, and another in the sense that the modern "utopia" in comparison with the preceding ... is deprived of ethical justifications. Both education and neo-liberal policies have been relegated to the role of accomplices in the hegemony of economic rationality. Education is positioned as a servant of the global economy, especially the economy of knowledge. At the national level and politically this means that education supports a very specific "policy of de-politicization" (Szkudlarek, 2013, p. 1).

T. Shkudlyarek's assessment of modern educational policy, deduced in the epigraph of this article (Szkudlarek, 2013, p. 1), is one of the brightest illustrations of the paradoxes of the beginning of the third millennium observed in the modern education system and all modern culture. These paradoxes are reflections of the "mutations" that are taking place in the modern social space, which, under the condition of their further spread, can in the near future produce serious mechanisms of civilization order with the prospect of the emergence of "post-human beings".

The deepest reason for the appearance of these paradoxes is the one observed at the beginning of the thirteenth century. The demarche of the neoliberal doctrine, the core of which is the idea that the state (the national state) not only doesn't stimulate the modern market (the global market) but, on the contrary, is a factor hindering its effective functioning. Such a frankly antistatist trend, which became a marker of the modern world order, was constantly fueled (and continues to feed) by different versions of the information society (knowledge society) and the newfangled models of so-called civic education. As a result, the traditional "education-policy" semantic field was replaced by the "educationeconomy" scheme, for the "servicing" of which a whole series of terms were invented (for example, "academic capitalism", "market pedagogy", "educational market", scientific knowledge as "financial goods", "academic manager").

With the goal of "legitimizing" this scheme, the idea of the need for reforming science and "scientific" education was formulated, because knowledge (scientific knowledge) was given the status of the main economic locomotive of social development. As a result, education becomes "a critical factor in the development of local and global markets; its ontological grounds and epistemic culture focus on economic incentives and are transformed under the influence of external doctrinal attitudes. Thus, the cognitive attitude of the educational type is modified in the mainstream of monetary trends, excluding the values of scientific production of truth. However, the latter is an indispensable condition for the creation of scientific innovations, underlying the processes of technological knowledge. Thus, the dominant contradiction of the modern era is emerging. It confronts the economic strategies of society with ontological and epistemic conditions for the reliability of these strategies, i.e. the contradiction between the total commodification of knowledge and the cultural-existential status of creative thought, which creates this knowledge. The development of this contradiction leads to the deconstruction of the ontological and epistemic bases of education. Hence the problem of arranging modern education, capable of overcoming the despair of a society "working on knowledge" (Karpov, 2015, p. 9). Essentially, the "culture of knowledge" that has been accumulated by mankind for centuries is being dismantled, which results in the destruction of the existential foundations (cultural and worldview foundations of life) that produce this knowledge. And this, in turn, drastically changes not only the 
very essence of the cognitive process but also the attitude towards it. The modern educational policy "destroys the being of the educational entity, which contains the truth about what exists, but at the same time, it is destroyed by this truth, which it cannot change. And in this confrontation, the disciple becomes a formal unit, a body devoid of thinking and a rush to the truth" (Karpov, 2015, p. 13).

To overcome the "educational and cultural" paradoxes of modernity, first of all, it is necessary to restore the status of a person as a spiritual and political entity, that is, to comprehend the true nature of man, which is possible only through consideration of the phenomenon of man in the historical perspective.

Contrary to the opinion of many modern researchers who call the state an abstraction or a historically transitory phenomenon, the entire cultural history of mankind, as well as contemporary political events, show that life in a state is a deep need of man as a spiritual being.

Aristotle argued that the state is the highest form of organization of human society and the ultimate goal of human development: "Since ... Every state is a kind of communication; any communication is organized for the sake of some good (any activity means the prospective good). Then, all communications tend ... to this or that good and more than others and the highest of all goods tends the communication which is the most important of all and embraces all other communications strives. This communication is called a state or a political communication" (Aristotle, $1984^{\mathrm{b}}$, p. 376). According to Aristotle, the state is the result of the natural process of completing the development of "primary communications", in which the "nature" of people's communication is manifested: “... we call the nature of each object ... its state, which is obtained at the completion of its development. Moreover, the higher completion consists in the accomplishment of the ultimate goal, and the self-sufficient existence turns out to be both an end and a supreme existence... the state belongs to that which exists by nature ... a man by nature is a political being and one who because of his nature, and not because of accidental circumstances, lives outside the state - either an underdeveloped in the moral sense of being or a superman ..." (Aristotle, $1984^{\text {b }}$, p. 378).

The etatism developed in the ancient political consciousness (the unconditional recognition of the state and society's priority over individualism) can be clearly traced, at least, to Hegel, who stated that a negative attitude toward the state and publicly acknowledged could rightfully be called not "freedom of thought" but "freedom of emptiness", which only through the destruction of something "feels itself existing; it believes, it is striving for some positive state, for example, for universal equality or universal religious life, but in fact it does not want the positive reality of this state, because such reality will immediately establish some order, some Isolation of both institutions and individuals. It is precisely from the destruction of this isolation and objective certainty that the self-consciousness of this negative freedom arises" (Hegel, 1990, pp. 7071).

The anti - etatism in the political consciousness begins to develop actively in the Modern Times with the ideas of democracy and civil society and with the principles of individualism and anarchy connected with these ideas. This line marked a departure from the recognition of the need for organic unity of the general and individual, society and man, the state and the citizen. This line finds its fullest expression in modern utopias, emphasizing the priorities of an individ- 
ual with his rights and freedoms, which, in essence, is evidence of the destruction of the spiritual and moral foundations of the social life of a single individual.

The state is a way of realising a deep (natural) human need for the realisation of a standard (universal) principle, which is the organic integrity of worldview orientations and meaningful orientations, with which history begins (the history of nations).

Strictly speaking, sociality (civilisation) is a product of the attribute property of a person which is spirituality. Objectified in the universals of culture (which expresses a unique system of social imperatives and transforms society into an ethos of the spirit), whose content is the higher meanings and goals of human life, spirituality is a dominant factor in integrating people into national communities. A mechanism that inscribes a person into by nature a national culture is the education system. It provides the cultural homogeneity necessary for the life of the nation. Therefore, the education system must be defined as the most critical institution of national culture, the basis for the formation and preservation of the nation and the nation state.

This reality was deeply realized in ancient times both in the East and in the West. The social life of the Oriental peoples - the Chinese, Indians, and Japanese - was determined by the Teacher-Student system, which serves as a means of preserving and developing the cultural tradition that assures the continuity of epochs and generations and the inviolability of the state structure. The education of public feelings was the basis of the national life of the ancient Greeks and Romans and the precondition for their legal capacity (Mirumyan, 2003, pp. 233-234).

Plato called politics a genuine science, that is, the science of Good - the "limit", the reason for everything correct and beautiful", necessary for the education and upbringing of citizens and the management of the development of the human community (Plato, 1994a, p. 517; Plato, $1994^{\mathrm{b}}$, p. 311). Defining the good (the highest good) as a goal, to which everything strives, Aristotle, in turn, believed that the comprehension of the good that determines the way of life of people is in the conduct of the science about the state (politics). It is politics which determines "what sciences are needed in the state and to what extent everyone should study... And since the science of the state uses the rest of the sciences as means and, also, legislatively determines what actions should be taken or which ones to abstain from, then its purpose includes the goals of other sciences, and, consequently, this goal will be the highest good for people... Even if for one person the good is the same as for the state, it seems more important and fuller after all the welfare of the state, its achievement and preservation. It is desirable..., of course, and [goods] of one person, but the goods of the people and the state is more beautiful and divine" (Aristotle, $1984^{\mathrm{a}}$, p. 55).

The ideas and principles of state education/upbringing formulated by ancient thinkers had a noticeable influence on the political and philosophical views of European thinkers up to the twentieth century.

In this regard, special attention deserves the German system of university education. An invaluable contribution in its development was made by the representative of the German classical philosophy J.G. Fichte. Having set himself the goal of the spiritual revival of the German nation, he developed a system of science teaching, which represents a project for the development of German society through the assimilation, development and dissemination of theoretical 
knowledge. According to Fichte's plan, university education is the most important way to ensure a high level of theoretical (scientific-philosophical) thinking and its spread in society. Only with the help of such an educational system the German nation will be capable of spiritual creativity and self-awareness (Fichte, 1993 ${ }^{\mathrm{a}}$, p. 636; Fichte, $1993^{\mathrm{b}}$, p. 556). The traditions of European University formed by Fichte in the twentieth century were continued by the German existentialist philosopher K. Jaspers, Professor of Heidelberg, and then of the University of Basel. The thinker called the university the centre of spiritual education of the people, and therefore it should represent for the state "the highest interest in its domestic policy". Jaspers explained his position by the fact that education provides the "ethnic future of the people" (Jaspers, 2000, p. 15).

Peter the Great was the first to create large scientific and educational center in Russia - the Academy (1747-1803), which included a university and a grammar school. The Moscow (1755) and Kazan (1758) universities were established in the middle of the XVIII century. Public education was the most important part of the state policy of the Russian state, and the evidence of this was the creation in 1802 of the Ministry of Education. Moreover, an efficient and advanced educational system based on the principle of universal education was formed in Russia in the late XIX-early XX centuries.

The following pattern can be revealed in the history of civilisation: the formation of nations and national cultures is accompanied by their political maturation, which finds its completion in the creation of a national state. In this triune process, a colossal role was played by the School (the system of education and upbringing), the mechanism for transferring to the subsequent generations the cultural experience of the nation, and through it the preservation and strengthening of national statehood. Therefore the following expression widespread in the 19th century is not accidental: "the French-Prussian war (1867-1871) was won by a German teacher".

However, the same history confirmed for the Armenian people another - an "exceptional" pattern. The Armenian system of national education is a unique cultural phenomenon designed to carry out an ethno-protective function in the absence of national statehood (from the fall of the Armenian kingdom in 428 to the Armenian Genocide in 1915). The life of the Armenian nation for many centuries was realized in the forms of a highly developed culture created by it. In the history of Armenian nation three periods of a particularly powerful upswing are distinguished: the transition from Antiquity to the Middle Ages, called the Golden Age or the Age of Enlightenment (5th century), a period of developed feudalism, called Silver Century (IX-XV centuries) and the period of the Armenian Renaissance (the end of the XVIII-XX centuries).

The first period is associated with two powerful factors of the spiritual life of the nation - the adoption of Christianity (301) and the creation of a national script (405) (Mirumyan, 2011, p. 85). The resultant powerful spiritual and intellectual movement is comparable according to the Europeans (Karl Ritter) with the development in Europe of the 15th century of sciences and arts. This movement was reduced to the construction of a unique spiritual model of national existence, which became a powerful tool for the nation's self-defence throughout the subsequent centuries of the existence of the Armenian people as a Christian people. The internal logic of the national culture of the 5th century is reproduced in the educational system, which is the main mech- 
anism for the Armenian people to enter the national and cultural traditions. Formed as a result of the creation of the national script, the National School was called upon together with the Armenian Apostolic Church, to ensure the identity of the Armenian nation. Thereby it contributed to the realization of the need to create (or rather, recreate) the national statehood in the historical perspective. National feelings, self-awareness and self-knowledge of the nation are the basis of its political aspirations, which, in turn, depend on the degree of its education and upbringing (Mirumyan, 2016, pp. 55-56).

The golden age of the Armenian culture predetermined the boundaries of the cultural cosmos of the nation, the features and the vector of the development of the national culture.

The silver age of Armenian culture is marked by the appearance in Armenia and in the Armenian Cilicia of numerous universities (about 15), where students received general and special education on the sections relevant to medieval scholarship departments. The totality of the disciplines studied at universities reflected the system of medieval scholarship.

The internal logic of the Armenian culture is reproduced in these large educational centres: "In the XIV century this relay takes the Tatev School in Syunik. The central point of its program is the ideological struggle against the scholasticism of the West that has spread in Armenia along with the movement of the Uniates (supporters of the unification of the Roman and Armenian churches). The opposition to the western religious (ideological) expansion carried out by the representatives of the Tatev school through the Apology of the Armenian Church, and the defence of its dogmatics was essentially aimed at upholding Armenia's national interests and preserving the identity and national character of its culture" (Mirumyan, 2016, pp. 306-307).

The period of the National Revival is characterized by a new wave of national enlightenment, which is the main means of assimilation and translation of the spiritual values of the nation. The program of a nationwide revival of the founder of the Armenian Order in Venice (1700) MkhitarSebastatsiwas to contribute to the nation's perception of its spiritual essence. It determines the specificity of the nation's existence and the possibility of its existence in history. The trends outlined by the Mkhitarianians were embodied in the XIX century, which is considered to be the second century of the Armenian Enlightenment. Armenian spiritual culture also in this century functioned as a spiritual unification of the nation. The successful implementation of this is evidenced by the fact that schools began to function in Armenia in this period (there were about 800 secondary schools, including women schools by 1870 in Western Armenia). Tens of thousands of books and about two thousand periodicals were published; dozens of theatres and theatre groups and printing houses were operating. The ideological core of the national education program of this period was the conviction of the Armenian spiritual elite in the idea that national education should be aimed at preserving and strengthening the national sentiment, otherwise the very essence of the Enlightenment changes. To revive and preserve the national sentiment, national enlightenment should be "harmonized" with the fundamental principles of national existence. This involves studying the history of the Christian religion and the Armenian Apostolic Church, the history of the Armenian people and the Armenian language in the National School. Given the fact that at that time Western Armenia (its "Turkish" part) was the scene of a clash of various ideologies (liberalism, the Cath- 
olic paradigm and Protestantism), it is hardly possible to overestimate the importance of the spiritual and moral opposition of the nation to the ideologies threatening its self-preservation. This opposition was expressed in the upsurge of national culture.

It is obvious that the education system of any nation predetermines the prospects of its historical (civil) development, as well as ways and means of resolving the problems that are ripening in the national community. Therefore, knowledge acts as a stimulant of the whole system of education. In the context of what has been said, the question arises: is the idea of a knowledgebased society, which became a symbol of the modern era, an initial premise for comprehending many realities of modernity and the cause of serious transformations of modern civilisation is "modern" enough?

History testifies that knowledge is a component of any culture, not only modern. Knowledge is a form of existence of culture and a way of existence of a person in it. Knowledge, in fact, is what ensures the interconnection of science and education, which is possible only in their historical development: "The initial element of understanding the connection between science and education is knowledge - the most important public property that determines the thinking level of the era and forms the basis of the spiritual "inheritance" of society. Knowledge doesn't form a simple sum of individual facts, but a complex integrated system that embodies opportunities, outcomes, prospects for knowledge and transformation of the world. It is comparable to the most global factors of society's existence" (Slutsky, 1980, p. 61).

Historically, science arose by an emerging social institution - the education system. At the same time, science is a form of existence of ready knowledge, which in turn is a means of carrying out cognitive activity to acquire new knowledge. Education, however, operates already ready-made knowledge. It is called upon to fulfil the functions of both teaching (the transfer and assimilation of knowledge, experience, skills) and education (the formation of a moral personality with a civic attitude and values), through which, in fact, the social nature of education is manifested. The historically determined process of mutual influence and interaction between science and education reveals both the "educational nature" of science and the "scientific nature" of education.

In the era of antiquity education was carried out within the framework of science. In the schools of Ancient Greece the functions of producing new scientific knowledge and education (the Academy of Plato and Aristotle's Lyceum) were simultaneously realized. In the first centuries of the Roman Empire "scientific education developed to its extreme height; it becomes increasingly common property and with the Latin language had spread across European provinces" (Schmidt, 1877, p. 419). The epoch of the Church Fathers was marked by the appearance of numerous philosophical, rhetorical, and law schools (Rome, Athens, Constantinople). In Alexandria, which was the centre of ancient science and education, attempts were made to "reconcile" Greek science and Christian doctrine (Philo of Alexandria).

In the Middle Ages education was predominantly theological and was carried out both in primary and secondary educational institutions and in higher educational institutions (madrassas, higher secular schools, universities - first they were Islamist, from the 12th century also European). Medieval universities were both a storehouse of knowledge and centres of educa- 
tion and science.

The noted tendency is also manifested in the Armenian spiritual culture. The creation of the national writing system (405) intensified the process of dissemination of education and the emergence of rich scientific literature. Schools and monasteries founded throughout Armenia involved different layers of Armenian society in the area of spiritual life, giving rise to a powerful cultural movement. The translation of the Bible (435), which recorded a very high level of the Armenian language, acquired special significance in the educational and scientific activities. Thanks to the translation of the Bible, the Armenian language became one of the literary languages of the time. The translation of the Bible had a great influence on the Armenian written literature (theological and philosophical treatises, historiography). The first ascetics of Armenian writing translated numerous monuments of ancient literature, which represented at that time all sections of the widely-spread classification of Christian Science and writing. Another line of development of ancient Armenian science was Graecophiling, whose representatives sought to bring to the Armenian culture the achievements of ancient science and philosophy. The translation activity of Graecophilswas carried out in accordance with the classification of sciences developed in the ancient world and adopted in the medieval education system.

Among the emerged major scientific and educational centres in Armenia and Armenian Cilicia (IX-XV centuries), the most famous were Gladzor (1291-1340) and Tatev (1390-1435). The set of studied disciplines, as already noted, reflected system of medieval education: ancient and medieval philosophy, theology, history, "seven free arts" - trivium (grammar, rhetoric, dialectics) and quadrium (arithmetic, geometry, cosmography, music theory), "practical arts" medicine, law, theory of calendar, pedagogue. There was a necessary literature in Armenian in all Armenian universities: both translated and original works of Armenian scientists and thinkers of past centuries were studied. Graduates were awarded academic degrees and titles "vardapet" (doctor of theology) and "imastaser" (philosopher, sophist).

The program of the national revival of the Armenians by MekhitarSebastatsi included the main directions of the spiritual development of the nation:

- Update of the Armenian language;

- Conductions of scientific research mainly in the field of classical philology, historiography, cartography, ethnography, philosophy, ethics, theology;

- Publication of the works of ancient Armenian thinkers and scientists;

- Translation of scientific and philosophical works of European authors;

- Educational activities carried out in various cities and regions of many countries (Transylvania, Hungary, Italy, France, Iran, Georgia, Crimea, Constantinople, etc.).

But the largest scientific and educational centre of the Mkhitaryans is the Academy (theological seminary) founded in September 1700 on the island of St. Lazarus (Venice).

Born in the bosom of Protestant ideology, the idea of European scientific education presupposed empirical studies of the laws created by God nature. The classical system of scientific education was theoretically substantiated by thinkers of the XVIII-XX centuries, beginning, at least, with I. Kant.

It is obvious that the idea of scientific education is an integral part of the centuries-old cultural tradition of the peoples of the world and 
therefore it is advisable today to talk only about the modern version of science and scientific education.

Culture is a constantly developing and enriching result of the creation of generations of a certain nation, in which the spiritual nature of this people is expressed, objectified in the system of knowledge created and produced by it. In each developed national culture the emphasis is placed (and this is specified by the conditions of national existence) on a certain type of knowledge, which determines the objectives of the educational system. At the same time a spiritual and moral component present in all forms of culture of a particular nation. It also determines the meaningful attitudes and view of this nation for its present and future. The system of education is aimed at understanding the nature of the creator and bearer of this culture. Because of this it initially contains a spiritual-moral dimension. The spiritual needs of the nation expressed in the original national culture contribute to the selfawareness of the individual and the creation of higher and absolute values (Mirumyan, 2014, p. 39).

Modernity has transformed the centuriesold cultural tradition. The entry of mankind into the knowledge society was marked by the fact that science ceased to act as a form of production of a true, universally valid, holistic knowledge of the world and man in it, thanks to which science for centuries had high cultural value. Modern society began to worship the cult of "useful", i.e. it is knowledge which has purely technological importance. In this way, the historically developed relationship between the fundamental and applied sciences was violated. Formation of the paradigm of functionalism acquired a scientific and theoretical status and laid the foundation for the computer era. It promoted the study of self- organizing systems (biological, social, technical).

The emergence and development of information approaches and information technologies highlighted the problem of transdisciplinarity.

In modern science - technology science there is a close combination of fundamental and applied levels of knowledge, which negates the importance of the theoretical level (scientific knowledge). This is manifested, mainly, in the rapid multiplication of empirical data, which is not enough systematized, and often isn't theoretically meaningful.

Market logic defines the "vital activity" of the whole system of production and consumption of modern scientific knowledge: "Science is experiencing a situation when the colossal multiplication of knowledge (mostly of an empirical nature) and the erosion of its fundamental principles leads to a rapid multiplication of problems over which we lose control, and thereby strategic perspective of our activities. This creates a feeling of ubiquitous uncertainty, the loss of solid ground under the feet, the scope for scepticism and relativism ... Such is the back side of the knowledge society, symbolizing the impasse of our consumer civilization" (Plato, 1994, p. 11).

The tendency indicated in modern science was reduced to the need based on economic conjuncture of educational system. And in this sense there is hardly a fundamental difference between the continuing to successfully "work" today classical liberal doctrine with its principles of political and economic individualism and the "philosophy of education" of the American neoconservatives of the $21^{\text {st }}$ century. In the context of the first (neoliberal) doctrine "pedagogy of the market builds a "new morality", which forms an "exhausted creature" at the output (attenuated creature). These "creatures" are independent and rational individuals who are "the only generators 
of their own desires and preferences and the best judges of their own interests. The choice is ... the key concept in the political articulation of these creatures ... it tears the fragile welfare discourse (while the state provides collective interests... and pursues a policy aimed at supporting all members of the civil society), and reaffirms the deeply rooted dogmas of the bourgeois Individualism..." (Ball, 2003, p. 32).

As for the "philosophy of education" of the American neoconservatives of the 21 st century, it is characterized by the implementation of the principle of secession of the school from the state and the removal of the state from the education sphere, also by the involvement of business in education to adapt the training centers to the conditions of a competitive global economy. As a result the ideological component of educational standards determined by the market mentality has sharply increased. Modern educational standards are nothing but a manifestation of the crisis of modern culture, the most important reflection of which was the crisis of culture of thinking.

Existing to date a large amount of research literature on the problem of the institute of modern education shows that there is still missing an integral, holistic and scientifically based concept of modern education. At the same time, there are some works (their number is constantly growing) of authors, in which the necessity of considering the system "science-education" outside the categories defining commodity-money relations is affirmed. This will be possible in case we identify, or rather, reconstruct in the context of the present day the essence of the scientific-cognitive and educational processes.

It is obvious that the ongoing trend of "economizing" all spheres of human and social life is fraught with very negative consequences of a cultural and civil nature. Such an approach undermines the very foundations of culture itself. After all, the culture of the production of knowledge "prescribes as its main condition the human ability to create new knowledge, and in a broader horizon the special spiritual competence "cogito", which is capable of enlivening knowledge" (Karpov, 2012, p.86).

It is obvious that the modern information society has displaced two hypostases of education - as a temporary self-reproducing socio-cultural phenomenon and a certain social structure programmed by man and society. Meanwhile, the basis of education is the desire to know all things, which is inherent to the person and not determined by economic categories. The present and future of the Institute of Education need to be understood in a broad cultural context; otherwise this Institute will finally become a regular financial corporation.

Education is the basis of social/national life. It naturally should be transformed in parallel with the changing political and socio-economic strategies of the nation-state. However, because of the desire to innovate in education, the fact that the educational system should always be oriented towards the education of a person and the formation of a citizen shouldn't be ignored. The education system is the cultural core of the life of a person and society. It contains timeless values and centuries-old national traditions. Without this, education loses its essential characteristics and simply turns into a "market for educational services". This is fraught with the disappearance of fundamental human qualities (Rousseau, 1907, p. 33).

The modern system of education (the system of socially controlled production of knowledge) boils down to the intellectual degradation of mankind and deepening of the anthropologi- 
cal crisis. The reason for this is seen in the trend of intellectual consumerism initiated by the system of modern education, skillfully veiled by the replacement of thinking with operational skills, and awareness with informativeness. Therefore, we should not talk about the crisis of the educational system, but about the crisis of man. Obviously, there is an urgent need to fundamentally rethink the goals and objectives of education. Its fundamental task should be to disclose in man his creative potential, the formation in him of a person capable of an intellectual effort.

To solve this problem, it is necessary to restore the status of those subjects in the curricula of higher education, the study of which contributes to the formation of a holistic vision of the world. First of all, we are talking about fundamental theoretical subjects in both areas of scientific knowledge (natural science and socio-humanitarian), as well as so-called "useless" subjects that do not directly work for specialization (philosophy, history, religion, art).Absence and insufficient attention to these subjects in the modern education system results in the release by universities of specialists who are practically devoid of personal, civil and spiritual-moral qualities. Meanwhile, there is a whole universe of spiritual and moral values that do not fit, and can't fit into the narrow scope of specialization and technological designs, as it is an expression of the deep essence of culture and civilization throughout the history of mankind. These values make up the core of that "useless" knowledge that is not in demand today in the modern consumer society. But the restoration of the status of this kind of knowledge can contribute to the survival of the national community, to overcome the economic crisis and to create innovations that are in demand in the modern social and political sit- uation in all spheres of life. To do this, it is necessary to create or restore national models of civic education that can bring citizens of a particular state first of all to their own, rather than global civil culture and to the system of spiritual values of their nation. These values make up the core of that "useless" knowledge that is not in demand today in the modern consumer society. But the restoration of the status of this kind of knowledge can contribute to the survival of the national community, to overcome the economic crisis and to create innovations that are in demand in the modern social and political situation in all spheres of life. To do this, it is necessary to create or restore national models of civic education that can bring citizens of a particular state first of all to their own, rather than global civil culture and to the system of spiritual values of their nation.

General civilization choice demanded by the modern global political situation can be realized only based on such a spiritual foundation. This choice is capable of overcoming the threat of destruction of the biological species of Homosapiens, or at least the recession of mankind to a pre-civilized state, which is imminent over all mankind.

\section{Conclusions}

1. The idea of the scientific education is part of the centuries-old culture of the peoples of the world. Therefore, today it is advisable to talk only about the modern version of scientific education.

2. The economization of education undermines the cultural and civilizational bases of the being of modern man and society.

3. The modern education system leads to intel- 
lectual degradation of man and to the deepening of anthropological crisis.

\section{REFERENCES}

Aristotle. (1984 ). Nikomakhova etika (Nicomachean Ethics, in Russian). Book One, Vol. 4. Moscow: Misl.

Aristotle. (1984 ). Politika (Policy, in Russian). Book One, Vol. 4. Moscow: Misl.

Ball, S. J. (2003).Social Justice in the Head. Are We all Libertarians Now? InV.Carol (Ed.) Social Justice, education and Identity (pp. 31-50). L.N.Y.: Routledge Falmer.

Fichte, J. G. $\left(1993^{\mathrm{a}}\right)$. Opyt novogo izlozheniya naukoucheniya (Experience of a New Exposition of the Science of Learning, in Russian). (Vol. 1). St. Petersburg: Miphril.

Fichte, J. G. $\left(1993^{\mathrm{b}}\right)$. Yasnoe kak solntse soobshchenie mirovoi publike o podlinnoi sushchnosti noveishei filosofii (Sun Clear Statement: the Message to the World about the True Essence of Modern Philosophy, in Russian). (Vol. 1). St. Petersburg: Miphril.

Hegel, G. V. F. (1990).Filosofiya prava.(The Philosophy of Right, in Russian). Moscow: Misl.

Jaspers, K. (2000). Ideya universiteta (The Idea of the University, in Russian). Topos, 3. Minsk.

Karpov, A. O. (2012). Kommodifikatsiya obrazovaniya $v$ rakurse ego celei, akseologii $i$ logiki kulturnogo dvizheniya (Commodification of Education in the Perspective of its Goals, Axiology and Logic of Cultural Movement, in Russian). Issues of Philosophy, 10, 85-96.
Moscow.

Karpov, A. O. (2015). Sotsialnaya i ekzistentsialnaya ontologiya obrazovaniya. (Social and Existential Ontology of Education, in Rassian).Issues of Philosophy, 1, 313. Moscow.

Materiali Kruglogo Stola: Problemi Philosophii (Materials of the Round Table: Issues of Philosophy, in Russian). (2015). Science. Technologies. Human, 9, 7-41. Moscow.

Mirumyan, R. A. (2003). Patmapilisopayakan hayecakargery' XIX dari hay pilisopayut'yan medj (Philosophical and Historical Concepts in the Armenian Philosophy of the XIX Century: Methodological Analysis, in Armenian). Yerevan: NoyanThapan.

Mirumyan, R. A. (2011). Armyanskoe kul'turnoe nasledie kak mekhanizm samozashchiti natsii $\mathrm{v}$ usloviyakh globalizatsii (k voprosu o politicheskoi kontseptsii kulturi) (Armenian Cultural Heritage as a Mechanism of National Self-Defense in the Context of Globalization (to the Question of the Political Concept of Culture), in Russian). Proceedings of the International Scientific Conference. Armenia in the Dialogue of Civilizations, April 28. (pp. 82 -90). Nizhny Novgorod.

Mirumyan, R. A. (2014). Chelovecheskoe izmerenie v sovremennoj sisteme obrazovaniya (politicheskij aspekt) (Human Measurement in the Modern System of Education (Political and Philosophical Aspect), in Russian). Psychology of the 21st Century: Theory, Practice, Prospect: Materials of the IV International Scientific Conference, February 15-16. 
(pp 35-44). Prague: Vědeckovydavatelské centrum «Sociosféra-CZ».

Mirumyan, R. A. (2016). Natsionalnii yazik kak pervoosnova cul'turnoii dentichnosti natsii (politico-philosophskij aspekt) (The National Language as the Primary Principle of the Cultural Identity of the Nation (Political and Philosophical Aspect), in Russian).Bulletin of the Russian - Armenian (Slavonic) University. Series: Humanities and Social Sciences, 47-62. Yerevan.

Mirumyan, R. A. (2016).Binom tserkvi i natsii kak opit osushchestvleniya universal'nogo v unikal'nom: $\mathrm{k}$ voprosu o spetsifike armyanskogo natsionalnogo samosoznaniya (politico-filosofskij aspekt) (Binomial of the Church and the Nation as an Experience of Universal Realization in a Unique: to the Issue of the Specifics of the Armenian National Identity (Political and Philosophical Aspect), in Russian). Materials of the International Scientific Forum: National Security Problems in the Context of
Globalization and Integration Processes (Interdisciplinary Aspects). (pp. 297309). Yerevan.

Plato. (1994). Politik (Politician, in Russian). (Vol. 4). Moscow: Misl.

Plato. (1994).Gosudarstvo (The State, in Russian). (Vol. 3). Moscow: Misl.

Rousseau, J.-J. (1907). Emil, ili o vospitanii (Emil, or on Education, in Russian). St. Petersburg: Izdatelstvo gazeti Shkola i Zhizn.

Schmidt, K. (1877). Istoriya pedogogiki v 4 tomakh (The History of Pedagogy in 4 volumes, in Russian). Publ. II. (4 Vols). Moscow: Tipografia imeni Martinova I. $\mathrm{K}$.

Slutsky, M. S. (1980). Nauka i obrazovanie. (Science and Education, in Russian) Science in Social, Epistemological and Value Aspects, 61-76. Moscow: Nauka.

Szkudlarek, T. (2013). Introduction: Education and the Political. In T. Szkudlarek (Ed.) Education and the Political.New Theoretical Articulations. (pp. 1-14). Rotterdam: Sense Publisthess. 